\title{
IDENTIFIKASI FAKTOR YANG MEMPENGARUHI PERTUMBUHAN BALITA PENDEK (STUNTING)
}

\author{
Ratna Roesardhyati ${ }^{1}$, Dedi Kurniawan ${ }^{2}$ \\ ${ }^{1}$ Institut Teknologi Sains dan Kesehatan (ITSK) RS. dr. Soepraoen, Malang. \\ ${ }^{2}$ Sekolah Tinggi IImu Kesehatan Kepanjen, Malang. \\ E-mail: ratnaroes@gmail.com
}

\begin{abstract}
Stunting in toddlers since the child's golden period needs special attention, which in turn can hinder the child's physical and mental development. Toddlers with stunting have a risk of experiencing decreased intellectual abilities, productivity, and an increased risk of suffering from degenerative diseases in the future. The aim of this study was to identify the factors that influence stunting. Case-Control Study with Comparison Group with purposive sampling is the approach used in this study. Respondents were divided into cases $(n=60)$ who were mothers with stunted children and control groups $(n=60)$ who were mothers with non-stunting children (normal). Both groups were subjected to an observational assessment and documentation study were analyzed with Biner Logistic Regression. The results showed that from the statistical analysis of five variables, namely maternal height, mother's education level, exclusive breastfeeding, birth weight for children under five, and giving complementary foods, it was found that three variables had a significant relationship with the incidence of stunting: mother's education level ( $p=$ 0.004. OR = 10.7), exclusive breastfeeding $(p=0.003$ OR $=7.8)$ and birth weight of children under five $(p$ $=0.028 O R=4.5)$. Statistically, the mother's education level is the most dominant factor relate to the incidence of stunting, followed by exclusive breastfeeding and under-five birth weight, respectively.According to this study, nurses and other health providers have to increase mothersknowledge about child parenting, exclusive breastfeeding and fulfillment of nutritional needs during pregnant to prevent low birth weight under five, so this effort could prevent stunting.
\end{abstract}

Keywords: stunting, nutrition, exclusive breastfeeding, growth and development

\begin{abstract}
Abstrak: Stunting pada balita sejak golden periods anak perlu menjadi perhatian khusus yang nantinya dapat menghambat perkembangan fisik dan mental anak. Balita stunting memiliki risiko mengalami penurunan kemampuan intelektual, produktivitas, dan peningkatan risiko menderita penyakit degeneratif di masa mendatang. Tujuan penelitian untuk mengidentifikasi faktor-faktor yang mempengaruhi stunting. Case Control Study with Comparison Group dengan purposive samplingmerupakan pendekatan yang didunakan pada penelitian ini. Responden dibagi dalam kelompok kasus $(n=60)$ yang merupakan ibu dengan anak stunting dan kelompok kontrol $(n=60)$ yang merupakan ibu dengan anak tidak stunting (normal). Kedua kelompok dilakukan penilaian observasi dan studi dokumentasi yang selanjutnya dianalisa menggunakan uji regresi logistik binear. Hasil penelitian menunjukan bahwa dari analisa statistik lima variabel yaitu tinggi badan ibu, tingkat pendidikan ibu, pemberian ASI eksklusif, berat badan lahir balita dan pemberian MPASI, diketahui bahwa terdapat tiga variabel yang memiliki hubungan signifikan terhadap kejadian stunting: tingkat pendidikan ibu ( $p=0,004 \quad O R=10,7)$, pemberian ASI eksklusif $(p=0,003$ OR=7,8) dan berat badan lahir balita $(p=0,028$ OR=4,5). Secara statistic, faktor tingkat pendidikan ibu menjadi faktor paling dominan hubungannya dengan kejadian stunting yang secara berurutan disusul oleh faktor pemberian ASI eksklusif dan berat badan lahir balita. Berdasarkan hal tersebut, penting bagi perawat dan tenaga kesehatan lain untuk meningkatkan pengetahuan lbu tentang pola asuh anak, pemberian ASI ekslusif dan pemenuhan kebutuhan nutrisi lbu hamil untuk mencegah berat badan lahir balita rendah, sehingga hal tersebut menjadi upaya pencegahan terjadinya stunting.
\end{abstract}

Kata Kunci :stunting, status gizi, ASI eksklusif, tumbuh kembang.

\section{PENDAHULUAN}

Masalah stunting menunjukkan
ketidakcukupan gizi dalam jangka waktu
panjang, yaitu kurang energi dan protein,
serta mikronutrien (De Onis, M. \& Branca,
F, 2016). Stunting pada balita sejak golden
periods anak perlu menjadi perhatian
khusus yangnantinya dapat menghambat
perkembangan fisik dan mental anak.
Risiko kesakitan dan kematian serta

terhambatnya pertumbuhan kemampuan motorik dan mental yang dialami oleh anak sangat erat hubungannya dengan adanya stunting. Masalah stunting yang dimaknai sebagai akibat kekurangan gizi jika tidak ditangani akan menimbulkan masalah serius bagi suatu negara, yaitu mengalami lost generation (Thomas, B \& Andre R.M.N., 2017).

Mengalami penurunan kemampuan intelektual, produktivitas, dan peningkatan 
risiko menderita penyakit degeneratif di masa mendatang merupakan risiko yang harus diterima oleh balita stunting (Abizari Abdul-Razak, 2017). Anak stunting cenderung lebih rentan mengalami gangguan kesehatan seperti penyakit infeksi, sehingga akan berisiko berdampak terjadinya penurunan kualitas kognitif. Stunting juga meningkatkan risiko obesitas, dimana orang dengan tubuh pendek maka akan memiliki berat badan ideal yang rendah. Kenaikan beberapa kilogram berat badan akan meningkatkan Indeks Massa Tubuh (IMT) yang melebihi batas normal. Keadaan overweight dan obesitas yang berlangsung dalam waktu yang lama akan meningkatan risiko terjadinya penyakit degeneratif.

Beberapa survei di Indonesia menunjukkan bahwa prevalensi anak usia Balita dari tahun 1992 sampai dengan 2020 Indonesia masih mengalami stunting sekitar 30-40 persen. Menurut data Riskesdas, tahun 2019 prevalensi anak balita pendek adalah $36,8 \%$ dan pada tahun 2020 dapat sedikit diturunkan menjadi $35,6 \%$. Namun penurunan tersebut masih belum sesuai dengan target RPJM tahun 2020 dimana harus diturunkan menjadi $32 \%$. Hal ini berarti hampir separuh balita di Indonesia memiliki masalah tinggi badan yang lebih rendah dibandingkan dengan standar tinggi badan balita seumurnya (Kementerian Kesehatan RI. 2018). Berdasarkan data tesebut diketahui bahwa Indonesia masih mengalami masalah stunting yang cukup serius dan harus segera ditangani. Prevalensi stunting di Jawa Timur saat ini juga tidak terpaut jauh dari angka prevalensi Nasional, yaitu mencapai 32,81 persen, padahal target RPJM pada tahun 2019 ditargetkan menjadi 28\% (Riskesdas, 2018). Provinsi Jawa Timur merupakan salah satu provinsi yang penurunan angka kejadian stunting kurang signifikan. Kabupaten Malangmerupakan salah satu bagian terluas dari wilayah di Jawa Timur dengan jumlah penduduk yang cukup besar. Menurut data Puskesmas dan Dinas Kesehatan Kab. Malang, Februari 2020, menunjukkan bahwa angka presentasi stunting sebesar $14,9 \%$ dari total balita, sedangkan rata-rata di Puskesmas sebesar 12\% (Provinsi Jawa Timur, D. K, 2019). Berdasarkan hal tersebut penulis tertarik untuk mengidentifikasi faktor-faktor yang mempengaruhi masalah gangguan pertumbuhan balita pendek (stunting).

\section{METODE PENELITIAN}

Desain penelitian analitik dengan case control study yang menggunakan metode observasi, wawancara, dan studi dokumentasi. Dalam penelitian ini, kelompok kasus adalah orang tua dengan balita pendek, sedangkan kelompok kontrol adalah orang tua dengan balita pertumbuhan normal. Peneliti membandingkan faktor yang berpengaruh terhadap pertumbuhan balita. Peneliti mengambil sampel dari data sekunder yang didapat dari buku catatan pengukuran BB dan TB dari Posyandu balita di Kecamatan Pagelaran sebagai kelompok kasus stunting dan kecamatan Turen sebagai kelompok kontrol. Dari data tersebut didapatkan sampel untuk balita pendek dan balita dengan balita dengan TB normal. Setelah mendapatkan data, peneliti kemudian menyebarkan kuesioner yang berisi identifikasi faktor resiko balita pendek. Kuesioner diisi oleh orang tua balita. Sebanyak 120 responden (balita dan orang tua) yang dibagi menjadi kelompok kasus (60 responden) dan kelompok kontrol (60 responden) telah terlibat dalam penelitian ini. Penentuan pertumbuhan balita dilihat dari buku SIP (Sistem Informasi Posyandu) yang sesuai dengan kriteria inklusi dan kriteria eksklusi pada penelitian ini, meliputi: 1) Sampel kasus, kriteria inklusi yang ditentukan untuk menetapkan sampel dalam penelitian ini meliputi a) orang tua beserta balita (usia kurang dari 5 tahun pada Mei 2019); b) terdaftar di posyandu lokasi penelitian ; b) tercatat dalam buku Posyandu sebagai balita dengan pertumbuhan tidak sesuai usia atau pendek/stunting (menurut TB/U standar Kemenkes). 2) Sampel kontrol, ditentukan dengan inklusi meliputi a) orang tua beserta balita (usia kurang dari 5 tahun pada Mei 2019); b) terdaftar di posyandu lokasi penelitian; b) tercatat dalam buku Posyandu sebagai balita dengan pertumbuhan sesuai usia atau normal (menurut TB/U standar Kemenkes).

Variabel terikat gizi buruk stunting adalah indikator status gizi pada anak usia di bawah 5 tahun yang dinilai berdasarkan usia dan tinggi badan. Pengukuran 
dilakukan dengan menyeimbangkan neraca digital dengan akurasi dua tempat desimal. Indeks didasarkan pada skor, yang merupakan standar deviasi tinggi badan normal menurut kriteria pertumbuhan WHO. Indeks Tinggi dan Usia WHO membatasi kelompok gizi anak di bawah 5 tahun untuk pertumbuhan yang terhambat. 2.0 SD dan normal: 2 SD (WHO, 2006). Variabel bebas meliputi tinggi badan ibu, tingkat pendidikan, usia ibu, status keuangan, pemberian ASI, berat badan lahir bayi, jenis kelamin bayi dan jenis makanan pendamping ASI.

\section{HASIL PENELITIAN}

Adapun karakteristik responden terdiri dari tinggi badan ibu, tingkat pendidikan ibu, umur ibu, status ekonomi keluarga, pemberian ASI, berat lahir balita, jenis kelamin balita dan jenis MPASI. Karekteristik responden tersebut disajikan pada tabel dibawah ini.

Tabel 1. Distribusi Frekuensi Subjek Berdasarkan Analisa Variabel Independen terhadap Kejadian Stunting $(n=120)$.

\begin{tabular}{|c|c|c|c|c|c|}
\hline \multirow{2}{*}{ Variable independen } & \multicolumn{2}{|c|}{ Kelompok kasus } & \multicolumn{2}{|c|}{ Kelompok kontrol } & \multirow{2}{*}{$p$ value } \\
\hline & $F$ & $\%$ & $f$ & $\%$ & \\
\hline Tinggi badan Ibu & & & & & 0.214 \\
\hline Berisiko $(\leq 145 \mathrm{~cm})$ & 26 & 43.4 & 19 & 31.7 & \\
\hline Tidak Berisiko $>145 \mathrm{~cm}$ & 34 & 56.6 & 41 & 68.3 & \\
\hline Tingkat pendidikan Ibu & & & & & 0.001 \\
\hline Rendah (tidak sekolah, SD, SMP) & 47 & 78.3 & 17 & 28.3 & \\
\hline Tinggi (SMA, Sederajat) & 13 & 21.7 & 43 & 71.7 & \\
\hline Umur Ibu & & & & & 0.418 \\
\hline Berisiko $(<20$ tahun atau $>35$ tahun) & 12 & 20 & 6 & 10 & \\
\hline Tidak Berisiko (20 - 35 tahun) & 48 & 80 & 54 & 90 & \\
\hline Status Ekonomi & & & & & 0.311 \\
\hline Rendah (< Rp. 1.337.650,-) & 44 & 73.3 & 40 & 66.7 & \\
\hline Tinggi (> Rp. 1.337.650,-) & 16 & 26.7 & 20 & 33.3 & \\
\hline Pemberian ASI & & & & & 0.001 \\
\hline Tidak eksklusif & 41 & 68.3 & 26 & 43.3 & \\
\hline ASI eksklusif & 19 & 31.7 & 34 & 56.7 & \\
\hline Berat lahir balita & & & & & 0.052 \\
\hline Kurang $(<2,5 \mathrm{~kg})$ & 16 & 26.7 & 5 & 8.3 & \\
\hline Cukup $(>2,5 \mathrm{~kg})$ & 44 & 73.3 & 55 & 91.7 & \\
\hline Jenis Kelamin balita & & & & & 0.319 \\
\hline Laki-laki & 18 & 30 & 27 & 45 & \\
\hline Perempuan & 42 & 70 & 33 & 55 & \\
\hline Pemberian MPASI & & & & & 0.003 \\
\hline Tidak sesuai (<umur 6 bulan) & 34 & 56.6 & 21 & 35 & \\
\hline Sesuai (>umur 6 bulan) & 26 & 43.4 & 39 & 65 & \\
\hline
\end{tabular}

Berdasarkan data pada Tabel 1, responden pada kelompok ibu stunting ditandai dengan risiko tinggi badan sebesar
Analisis data awal diperiksa untuk konsistensi antar variabel (uji kolinieritas). Kemudian, pemilihan variabel dilakukan dalam dua uji coba yang berbeda. Untuk variabel dikotomis dijalankan dalam Chidijalankan di Uji-T. Pada langkah terakhir, kami menggunakan uji regresi logistik biner untuk menentukan apakah variabel independen yang diuji termasuk sebagai faktor yang mempengaruhi timbulnya stunting pada anak di bawah usia 5 tahun. square dan untuk variabel kontinu 
$31,7 \%$. Pada tingkat pendidikan, balita stunting dengan tingkat pendidikan ibu yang rendah yaitu sebesar $78,3 \%$, sedangkan balita yang tidak stunting dengan tingkat pendidikan ibu yang rendah sebesar $28,3 \%$. Kelompok keluarga berpenghasilan rendah menyumbang $73,3 \%$, sedangkan kelompok kontrol berpenghasilan rendah menyumbang $66,7 \%$. Pada pemberian ASI Eksklusif, balita yang tidak diberikan ASI Eksklusif dan mengalami stunting yaitu sebesar $68,3 \%$, sedangkan balita yang diberi ASI Eksklusif dan tidak mengalami stunting yaitu sebesar $56,7 \%$. Pada berat lahir bayi, balita stunting dengan berat lahir kurang dari $2,5 \mathrm{~kg}$ yaitu sebesar $26,7 \%$, sedangkan balita yang tidak stunting dengan berat lahir cukup yaitu sebesar $91,7 \%$. Balita stunting dengan jenis kelamin laki-laki yaitu sebesar $30 \%$, sedangkan balita tidak stunting berjenis kelamin lakilaki yaitu sebesar $45 \%$.

Tabel 2. Seleksi Kandidat Analisis Multivariat Berdasarkan Analisa Bivariat Variabel Independen terhadap Kejadian Stunting ( $\mathrm{n}=120)$.

\begin{tabular}{ccc}
\hline No & Variable independen & $\boldsymbol{p}$ value \\
\hline 1 & Tinggi badan Ibu & 0.214 \\
2 & Tingkat pendidikan Ibu & 0.001 \\
3 & Umur Ibu & 0.418 \\
4 & Status Ekonomi & 0.311 \\
5 & Pemberian ASI & 0.001 \\
6 & Berat lahir balita & 0.052 \\
7 & Jenis Kelamin balita & 0.319 \\
8 & Pemberian MPASI & 0.003 \\
\hline
\end{tabular}

Berdasarkan di atas (tabel 2) seleksi kandidat analisis multivariat diatas menunjukkan bahwa terdapat lima variabel independen yang memiliki nilai $p<0,25$ dan memenuhi syarat untuk dilakukan analisis multivariate. Variabel yang dilakukan analisis multivariate meliputi tinggi badan ibu, tingkat pendidikan ibu, pemberian ASI eksklusif, berat badan lahir balita dan pemberian MPASI. Variabel-variabel tersebut kemudian dimasukkan dalam pemodelan analisis multivariat. Kemudian dikeluarkan variabel-variabel yang memiliki $p$ value $>0,05$, dimulai dari variabel dengan $p$ value yang paling besar secara bertahap (metode backward selection). Pemodelan analisis multivariat ditampilkan dalam tabel 3 berikut.

Tabel 3. Hasil Analisis Multivariat Variabel Independen terhadap Kejadian Stunting $(n=120)$

\begin{tabular}{llllllll}
\hline No & \multirow{2}{*}{ Variabel } & \multicolumn{2}{c}{ Model I } & \multicolumn{2}{c}{ Model II } & \multicolumn{2}{c}{ Model III } \\
\cline { 3 - 8 } & & $\boldsymbol{p}$ value & OR & $\boldsymbol{p ~ v a l u e}$ & OR & $\boldsymbol{p}$ value & OR \\
\hline 1 & Tinggi badan Ibu & 0.112 & 3.4 & 0.089 & 3.8 & - & - \\
2 & Tingkat pendidikan & 0.017 & 6.0 & 0.007 & 7.2 & 0.004 & 10.7 \\
3 & Pemberian ASI & 0.011 & 5.1 & 0.004 & 6.8 & 0.003 & 7.8 \\
4 & Berat lahir & 0.092 & 4.0 & 0.041 & 4.3 & 0.028 & 4.5 \\
5 & Jenis Kelamin & 0.237 & 14.0 & - & - & - & - \\
\hline
\end{tabular}

Berdasarkan hasil analisis pada Tabel 3 menunjukkan bahwa Model I analisis multivariat, variabel jenis kelamin balita merupakan variabel dengan nilai $p$ paling besar, sehingga dikeluarkan dari pemodelan. Model II menunjukkan bahwa variabel tinggi badan ibu merupakan variabel yang memiliki nilai $p$ value yang paling besar, sehingga dikeluarkan dari pemodelan II. Terdapat tiga variabel yang masuk pada analisis model III, yaitu: tingkat

pendidikan ibu, pemberian ASI eksklusif, dan berat badan lahir balita. Model III menunjukkan bahwa variabel tingkat pendidikan ibu memiliki $p<0,05$ dan nilai $O R$ paling besar $(O R=10.7)$. Sehingga dapat disimpulkan bahwa variabel tingkat pendidikan ibu merupakan variabel yang memiliki hubungan paling dominan dengan 
kejadian balita stunting di wilayah kerja Puskesmas Kecamatan Turen Kabupaten
Malang.

faktor penting terjadinya stunting (Rahmad AHAL \& Miko A,2016).

Masalah pertumbuhan anak

Penelitian ini dilakukan untuk mengidentifikasi faktor-faktor yang mempengaruhi masalah gangguan pertumbuhan balita pendek (stunting). Faktor-faktor yang diteliti dalam penelitian ini meliputi tinggi badan ibu, tingkat pendidikan ibu, umur ibu, status ekonomi, pemberian ASI eksklusif, berat badan lahir balita, jenis kelamin balita dan pemberian Makanan Pendamping ASI (MPASI). Berdasarkan seleksi analisis kandidat variabel yang dianalisis multivariat didapatkan lima variabel yang memenuhi syarat yaitu tinggi badan ibu, tingkat pendidikan ibu, pemberian ASI eksklusif, berat badan lahir balita dan pemberian MPASI.

Hasil analisis secara statistik menunjukkan bahwa terdapat tiga variabel yang masuk pada analisis model, yaitu: tingkat pendidikan ibu, pemberian ASI eksklusif, dan berat badan lahir balita. Variabel tingkat pendidikan ibu memiliki nilai $p<0,05$ dan nilai OR paling besar (OR=10.7). Variabel yang memiliki hubungan paling dominan dengan kejadian balita stunting di wilayah kerja Puskesmas Kecamatan Turen Kabupaten Malang adalah variabel tingkat pendidikan ibu. Hasil penelitian ini sejalan dengan penelitian Setiawan, E., Machmud, R., \& Masrul (2018) bahwa tingkat pendidikan ibu dengan kejadian stunting pada anak memiliki hubungan yang signifikan. Hasil penelitian lain yang dilakukan di wilayah Puskesmas Cempaka, Banjarbaru, Kalimantan Selatan bahwa terdapat hubungan signifikan antara tingkat pendidikan ibu dengan kejadian stunting pada anak (Rahayu, A \& Khairiyati, L, 2014).

Tingkat pendidikan ibu menjadi salah satu faktor dominan yang berhubungan dengan kejadian stunting. Tingkat pendidikan ibu berpengaruh terhadap kesehatan diri dan keluargasertapola pengasuhan anak. Pengetahuan ibu tentang pemenuhan kebutuhan nutrisi anak dan stimulasi tumbuh kembang anak menjadi salah satu termasuk terjadinya stunting sangat dipengaruhi oleh asupan nutrisi yang diperoleh sejak bayi lahir. (Humphrey et al, 2019). Nutrisi yang paling tepat bagi balita adalah ASI (Hindrawati N,\& Rusdiarti,2018). Variabel penelitian pemenuhan kebutuhan ASI eksklusif dalam penelitian ini menunjukkan hubungan yang signifikan terhadap terjadinya stunting di wilayah Kecamatan turen ( $p<0,003$ dan OR 7,8$)$. Pemberian ASI eksklusif sebagai upaya memenuhi kebutuhan nutrisi utama balita dimulai sejak bayi baru lahir hingga 6 bulan (Kementerian Kesehatan RI, 2018). Beberapa faktor yang umum menjadi penyebab terjadinya stunting yaitu tidak dilakukan proses inisiasi menyusu dini (IMD) oleh ibu, kegagalan program ASI eksklusif, dan proses penyapihan ASI yang terlalu dini (Damayanti RA, Muniroh L, \& Farapti,2016).

Berbeda dengan variabel MPASI, tidak menunjukkan hubungan yang signifikan antara pemberian MPASI dengan kejadian stunting. Hal ini kemungkinan disebabkan karena pada faktor pemberian MPASI pada penelitian ini hanya menilai terkait kesesuaian waktu pemberian MPASI pertama kali yaitu $<6$ bulan atau $>6$ bulan. bahwa yang perlu diperhatikan dalam program MPASI adalah aspek kuantitas, kualitas, dan keamanan pangan yang diberikan. Hal ini disebabkan karena asupan zat gizi pada balita merupakan kebutuhan utama dalam mendukung pertumbuhan balita sesuai dengan grafik pertumbuhannya, sehingga mencegah terjadinya kegagalan pertumbuhan (growth faltering) seperti stunting (De Onis et al, 2013; Laksono, A.D \& Megatsari, H. 2020).

Status kesehatan dan gizi ibu hamil sebelum, selama, dan setelah melahirkan mempengaruhi risiko perkembangan janin dan stunting. Faktor lain yang mempengaruhi ibu adalah tinggi badan ibu (pendek), jarak antar kehamilan yang terlalu dekat, usia ibu masih remaja, dan Sedangkan menurut literatur menyebutkan 
kekurangan gizi selama kehamilan (Laksono, A. D et al, 2019).

Faktor yang memperburuk kondisi ibu hamil adalah terlalu muda, terlalu tua, terlalu banyak melahirkan, atau terlalu dekat dengan tenggat waktu. Usia kehamilan ibu terlalu muda (di bawah 20 tahun) untuk melahirkan bayi dengan berat badan lahir rendah (BBLR). Bayi berat lahir rendah mempengaruhi sekitar $20 \%$ stunting (Laksono, A. D et al, 2019; Abizari AbdulRazak, 2017). Data Riskesdas tahun 2018, diketahui proporsi kehamilan pada remaja usia $10-14$ tahun sebesar $0,02 \%$ dan usia 15-19 tahun sebesar $1,97 \%$. Proporsi kehamilan pada remaja lebih banyak terdapat di perdesaan daripada perkotaan. Menurut data Susenas tahun 2018, hasil survei pada perempuan berumur 15-49 tahun diketahui bahwa $54,01 \%$ hamil pertama kali pada usia di atas 20 tahun (usia ideal kehamilan).Sisanya sebesar $23,79 \%$ hamil pertama kali pada usia $19-20$ tahun, $15,99 \%$ pada usia $17-18$ tahun, dan $6,21 \%$ pada usia 16 tahun ke bawah. Hal ini menunjukkan bahwa separuh dari ibu hamil Indonesia hingga saat ini telah mengalami kehamilan pertama saat masih anak-anak atau remaja.

Hasil penelitian ini secara statistik menunjukkan bahwa pada faktor usia ibu menunjukkan tidak ada hubungan yang signifikan, hal ini kemungkinan disebabkan karena usia ibu saat melahirkan antara kelompok kasus dan kelompok kontrol adalah homogen. Sehingga hal tersebut secara analisis statistik tidak menunjukkan perbedaan yang signifikan.

Faktor kondisi ibu yang dianalisis dalam penelitian ini selain usia yaitu terkait faktor tinggi badan ibu. Status ibu sebelum hamil, postur tubuh (berat dan tinggi badan) dan status gizi merupakan beberapa faktor yang mempengaruhi perkembangan anak stunting (Laksono, A. D et al, 2019). Remaja putri sebagai calon ibu perlu mendapat asupan gizi dengan baik. (Humphrey et al, 2019). Hasil penelitian ini secara statistik menunjukkan bahwa pada faktor tinggi badan ibu menunjukkan tidak ada hubungan yang signifikan, hal ini kemungkinan disebabkan karena tinggi badan ibu saat sebelum kehamilan sampai melahirkan antara kelompok kasus dan kelompok kontrol adalah homogen. Sehingga hal tersebut secara analisis statistik tidak menunjukkan perbedaan yang signifikan.

Faktor sosial ekonomi pada penelitian ini menunjukkan bahwa tidak terdapat hubungan yang signifikan sehingga dikeluarkan dari permodelan. Hal ini menurut peneliti disebabkan karena responden dalam penelitian ini sebagian besar berada pada wilayah demografi pedesaan dengan rata-rata status ekonomi menengah kebawah. Diketahui bahwa status sosial ekonomi dan kebersihan perumahan juga berhubungan dengan stunting (Rahman, M. S et al., 2016). Status ekonomi berkaitan erat dengan kemampuan ibu hamil dan anak kecil untuk mengakses layanan gizi dan kesehatan. Sedangkan sanitasi dan keamanan pangan dapat meningkatkan risiko terjadinya penyakit infeksi. (Cameron, L., Olivia, S., \&Shah, M, 2019; Lisa Camerona et al, 2021).

Berdasarkan data dari Joint Child Malnutrition Estimates tahun 2018, prevalensi stunting dapat menurun sebesar $64 \%$ di negara-negara kelas ekonomi menengah atas, tetapi penurunan kecil angka stunting sekitar $24 \%$ antara tahun 2000 dan 2017 di negara-negara kelas ekonomi menengah. Sementara di negara kelas ekonomi rendah justru mengalami peningkatan pada tahun 2017 (Badan Pusat Statistik, 2017; Rosmalina Y et al, 2018).

Infeksi akibat sanitasi dan higiene yang buruk (seperti diare dan cacingan) dapat mengganggu penyerapan nutrisi selama proses pencernaan (Lisa Camerona et al., 2021). Beberapa infeksi yang didapat pada anak dapat menyebabkan anak mengalami penurunan berat badan (Cameron, L., Olivia, S. \& Shah, M, 2019). Jika kondisi ini berlangsung lama dan proses penyembuhan tidak mendapat nutrisi yang cukup, dapat menyebabkan pertumbuhan terhambat dan stunting.

Hasil dari penelitian ini yang bertujuan mengidentifikasi faktor-faktor yang mempengaruhi masalah gangguan pertumbuhan balita pendek (stunting) harapannya dapat menjadi sumber referensi guna menentukan strategi pencegahan dan penanganan stunting khususnya di wilayah Kabupaten Malang. Diketahui bahwa stunting berdampak mengalami gangguan perkembangan otak yang mempengaruhi kemampuan kognitif dalam jangka pendek. Kehilangan 
kemampuan jangka panjang yang berkurang untuk menerima pendidikan yang lebih baik dan kesempatan kerja dengan gaji lebih tinggi (Lisa Camerona et al., 2021). Dalam jangka panjang, anak stunting yang lebih berpeluang untuk bertahan hidup hingga dewasa lebih cenderung mengalami kelebihan berat badan (obesitas) dan meningkatkan risiko mengalami penyakit

\section{KESIMPULAN DAN SARAN}

Kejadian stunting pada balita dipengaruhi oleh tiga faktor yaitu tingkat pendidikan ibu, pemberian ASI eksklusif, dan berat badan lahir balita. Faktor tingkat pendidikan ibu menjadi faktor paling dominan hubungannya dengan kejadian stunting yang secara berurutan disusul oleh

\section{DAFTAR PUSTAKA}

Abizari Abdul-Razak. 2017. The effect of maternal and child factors on stunting, among children under-5 years in Nigeria: A multilevel analysis. Nigeria: BMC

Aridiyah, F.A., Rohmawati, N., \& Ririanty, M.. 2015. Faktor-faktor yang Mempengaruhi Kejadian Stunting pada Anak Balita di Wilayah Pedesaan dan Perkotaan.e-Jurnal Pustaka Kesehatan, 3 (1): 163-170

Aryastami, N. K., Shankar, A., Kusumawardani, N., Besral, B., Jahari, A. B., \& Achadi, E. 2017. Low birth weight was the most dominant predictor associated with stunting among children aged 12-23 months in Indonesia. BMC Nutrition, 3, 16. https://doi. org/10.1186/s40795-0170130-x

Badan Pusat Statistik. 2017. Statistik Kesejahteraan Rakyat Tahun 2017. Jakarta.

Burt Thomas, and Renzaho Andre M.N. 2017. Stunting and severe stunting

Cameron, L., Olivia, S., Shah, M., 2019. Scaling-up sanitation: evidence from an RCT in Indonesia. J. Dev. Econ. 138 (May), 1-16.

Damayanti RA, Muniroh L, Farapti. 2016. Perbedaan tingkat kecukupan zat gizi dan riwayat pemberian ASI eksklusif tidak menular (PTM) seperti hipertensi, diabetes, hipertensi, kanker dan penyakit lainnya akan lebih tinggi. Semua kondisi ini menjadi semakin nyata di Indonesia, menunjukkan bahwa PTM meningkat antara tahun 2007 dan 2013, dengan perkiraan 70 juta orang dewasa (berusia 18+) menderita PTM.

faktor pemberian ASI eksklusif dan berat badan lahir balita. Hasil dari penelitian ini yang bertujuan mengidentifikasi faktorfaktor yang mempengaruhi masalah gangguan pertumbuhan balita pendek (stunting) harapannya dapat menjadi sumber referensi guna menentukan strategi pencegahan dan penanganan stunting khususnya di wilayah Kabupaten Malang.

pada balita stunting dan non stunting. Media Gizi Indonesia. 11(1):61-9.

De Onis, M. \& Branca, F. 2016. Childhood stunting: A global perspective. Matern. Child Nutr. 12, 12-26.

De Onis, M., Dewey, K. G., Borghi, E., Onyango, A. W., Bl"ossner, M., Daelmans, B., \& Branca, F. 2013. The world Health Organization's global target for reducing childhood stunting by 2025: Rationale and proposed actions. Maternal \& Child Nutrition, 9, 6-26.

https://doi.org/10.1111/mcn.12075

Hindrawati N, Rusdiarti. 2018. Gambaran riwayat pemberian ASI eksklusif dengan kejadian stunting pada anak usia 6-24 bulan di Desa Arjasa Kecamatan Arjasa Kabupaten Jember. JKAKJ. 2(1):1-7.

Humphrey, J.H., Mbuya, M.N., Ntozini, R., Moulton, L.H., Stoltzfus, R.J., Tavengwa, N. V., Chasokela, C.M., 2019. Independent and combined effects of improved water, sanitation, and hygiene, and improved complementary feeding, on child stunting and anaemia in rural Zimbabwe: a cluster-randomised trial. Lancet Glob. Health 7 (1), e132-e147. Kemenkes RI. 2017. Data dan Informasi Profil Kesehatan Indonesia 2016. Pusat Data dan Informasi:Jakarta. 
Kemenkes. Buletin Stunting. Kementeri. Kesehat. Republik Indonesia. 301, 1163-1178 (2018).

Kementerian Kesehatan RI. 2018. Buku Saku Pemantauan Status Gizi Tahun 2017. Jakarta.

Laksono, A. D., Ibad, M., Mursita, A., Kusrini, I. \& Wulandari, R. D. 2019. Characteristics of mother as predictors of stunting in toddler. Pakistan J. Nutr. 18, 1101-1106.

Laksono, A.D \& Megatsari, H. 2020. Determinan Balita Stunting di Jawa Timur: Analisis Data Pemantauan Status Gizi 2017. Amerta Nutr.109$115 \quad 110 \quad$ DOI: 10.2473/amnt.v4i2.2020.109-115

Lisa Camerona, Claire Chaseb, Sabrina Haquec, George Josephb, Rebekah Pintob, Qiao Wang. 2021. Childhood stunting and cognitive effects of water and sanitation in Indonesia. Economics and Human Biology. 40 (2021) 100944

Mugianti, S., Mulyadi, A., Anam, A.K., \& Najah, Z.L. 2018. Faktor penyebab anak Stunting usia 25-60 bulan di Kecamatan Sukorejo Kota Blitar. Jurnal Ners dan Kebidanan, 5(3): 268-278

Provinsi Jawa Timur, D. K. 2019. Profil Kesehatan Jawa Timur 2018. 100.

Rahmad AHAL, Miko A. 2016. Kajian stunting pada anak balita berdasarkan pola asuh dan pendapatan keluarga di
Kota Banda Aceh. Banda Aceh. Jurnal Kesmas Indonesia. (2):63-79.

Rahman, M. S., Howlader, T., Masud, M. S., \& Rahman, M. L. 2016. Association of low-birth weight with malnutrition in children under five years in Bangladesh: do mother's education, socio-economic status, and birth interval matter? PloS one 11, e0157814.

https://doi.org/10.1371/journal.pone.0 157814

Rosmalina Y, Luciasari E, Aditianti, Ernawati F. 2018. Upaya pencegahan dan penanggulangan batita stunting: systematic review. Jurnal Gizi Indonesia. 41(1):1-14.

Setiawan, E., Machmud, R., \& Masrul. 2018. Faktor-Faktor yang Berhubungan dengan Kejadian Stunting pada Anak Usia 24-59 Bulan di Wilayah Kerja Puskesmas Andalas Kecamatan Padang Timur Kota Padang Tahun 2018. Jurnal Kesehatan Andalas. 7(2): 275-284

Vaozia S, Nuryanto. 2016. Faktor risiko kejadian stunting pada anak usia 1-3 tahun (studi di Desa Menduran Kecamatan Brati Kabupaten Grobogan). Journal of Nutrition College. 5(4):314-20.

WHO Multicentre Growth Reference Study Group, de Onis, M.. 2006. Assessment of differences in linear growth among populations in the WHO Multicentre Growth Reference Study. Acta Paediatrica, 95, 56-65. 